\title{
The Eco-Evolutionary Imperative: Revisiting Weed Management in the Midst of an Herbicide Resistance Crisis
}

\author{
Fabian D. Menalled ${ }^{1, *}$, Robert K. D. Peterson ${ }^{1}$, Richard G. Smith ${ }^{2}$, William S. Curran ${ }^{3}$, \\ David J. Páez ${ }^{1}$ and Bruce D. Maxwell ${ }^{1}$ \\ 1 Department of Land Resources and Environmental Sciences, Montana State University, Bozeman, \\ MT 59717-3120, USA; bpeterson@montana.edu (R.K.D.P.); dpaezmc@gmail.com (D.J.P.); \\ bmax@montana.edu (B.D.M.) \\ 2 Department of Natural Resources and the Environment, University of New Hampshire, Durham, \\ NH 03824, USA; richard.smith@unh.edu \\ 3 Department of Plant Sciences, Penn State University, University Park, PA 16802, USA; wsc2@psu.edu \\ * Correspondence: menalled@montana.edu; Tel.: +1-406-994-4783
}

Academic Editor: Carol Shennan

Received: 14 October 2016; Accepted: 3 December 2016; Published: 9 December 2016

\begin{abstract}
Modern weed science is at a crossroads. Born out of advances in chemistry, it has focused on minimizing weed competition with genetically uniform crops and heavy reliance on herbicides. Paradoxically, the success obtained with such an approach and the reluctance to conduct integrated and multidisciplinary research has resulted in unintended, but predictable, consequences, including the selection of herbicide resistant biotypes. Advances in eco-evolutionary biology, a relatively recent discipline that seeks to understand how local population dynamics arise from phenotypic variation resulting from natural selection, habitat distribution, and propagule dispersal across the landscape are transforming our understanding of the processes that regulate agroecosystems. Within this framework, complementary tactics to develop alternative weed management programs include the following: (1) weed scientists must recognize that evolution occurs within crop fields at ecologically-relevant time scales and is rooted in the inherent variation that exists in all populations; (2) weed management should recognize that the probability of a resistant mutant is directly related to the population size; (3) farmers need to acknowledge that herbicide resistance transcends any one farm and should coordinate local practices with regional actions; (4) incentives should be developed and implemented to help the adoption of eco-evolutionary management programs; and (5) risk analysis can help incorporate an eco-evolutionary perspective into integrated weed management programs.
\end{abstract}

Keywords: eco-evolutionary feedbacks; weed ecology and management; multiple herbicide resistance; modelling; risk assessment

\section{Eco-Evolutionary Thinking and Weed Management}

In 1973, Theodosius Dobzhansky, a prominent geneticist and one of the founders of the neo-Darwinian evolutionary synthesis, published an influential essay titled "Nothing in biology makes sense, except in the light of evolution" [1]. In it, he argues that as a cornerstone of every biological process, evolution should be a central tenet in all areas of life science research and education, including agriculture. Indeed, since the inception of agriculture, farmers have taken advantage of the principles of evolution to increase yields and diversify varieties of crops and livestock, and one of Darwin's primary arguments for the importance of natural selection was its similarities with the artificial selection process occurring in agriculture [2,3]. More recently, several authors highlighted the 
importance of incorporating an eco-evolutionary framework in the management of agroecosystems to strengthen crop resilience to future climatic conditions and meet projected food and ecosystem services demands [4-8].

While ecologists have historically assumed that evolution occurs over temporal scales too long (i.e., centuries to millennia) to affect organisms over ecologically-relevant time scales (i.e., days to years) [9], evolutionary biologists often interpreted findings in terms of the mechanisms generating phenotypic diversity in organisms. Yet, work over the last three decades has shown that the rate of adaptation (i.e., the increase in fitness due to a better "match" between phenotypes and their environment) is much faster than anticipated [10-13]. Furthermore, theoretical and empirical work has demonstrated that evolution can not only regulate populations [14-16], but also ecological interactions such as host-pathogen [17,18], predator-prey [19-21], and competition [22]. Although feedback between ecological interactions and evolution were first discussed almost sixty years ago [16], new research has re-kindled interest in these feedbacks, also known as eco-evolutionary dynamics [23,24]. The field of eco-evolutionary biology seeks to understand how eco-evolutionary dynamics arise from phenotypic variation resulting from natural selection, habitat distribution (e.g., connectivity), and propagule dispersal across the landscape [25-27].

The analysis of eco-evolutionary dynamics is transforming our understanding of the processes that regulate agroecosystems [4]. An eco-evolutionary perspective to agriculture acknowledges the impact that anthropogenic factors, such as climate change, land-use change, global mixing of species, and agricultural disturbances have in influencing interactions between crops and associated biodiversity [28]. Among the benefits that an eco-evolutionary perspective can provide to agroecosystem design and management are insights necessary to (1) use rapid evolution to help adapt crops to their environment; (2) facilitate the establishment of communities of beneficial organisms that regulate pest populations; and (3) reduce selection for pest genotypes that are resistant to control practices.

In the context of weed management, an eco-evolutionary perspective can help us understand pressing management challenges such as the evolution and spread of herbicide resistant biotypes (i.e., the adaptive process by which a weed biotype acquires the ability to survive and reproduce after exposure to an herbicide that should have been lethal). By contrast to eco-evolutionary dynamics in nature, the farming practices that impose selection on weeds has a major role in determining the ecological interactions occurring within cropping systems. Most annual cropping systems can be characterized as highly simplified and disturbed habitats where artificially selected plants (i.e., crops) interact with a variety of other species (i.e., associated agro-diversity that includes plants, animals, microorganisms, etc.) occurring on the same or different trophic level [29]. Components of the associated agro-diversity inevitably evolve in response to the human-driven selective pressures imposed by agricultural management practices, resulting in the emergence of newly-adapted genotypes, including weeds that are herbicide resistant. Herbicide resistance can be seen as an eco-evolutionary process because: (1) increased weed density leads to the application of highly efficient herbicides which leads to strong selection; (2) selection for herbicide resistance then affects the genetic composition of the weed population leading to adaptation; (3) adaptation, again, leads to increases in weed density; and (4) the management of these newly-adapted genotypes results in different selective pressures (e.g., use of additional herbicides or mechanical cultivation) (Figure 1). However, management programs aimed at minimizing the selection for herbicide resistant weeds do not generally consider these feedback mechanisms. 


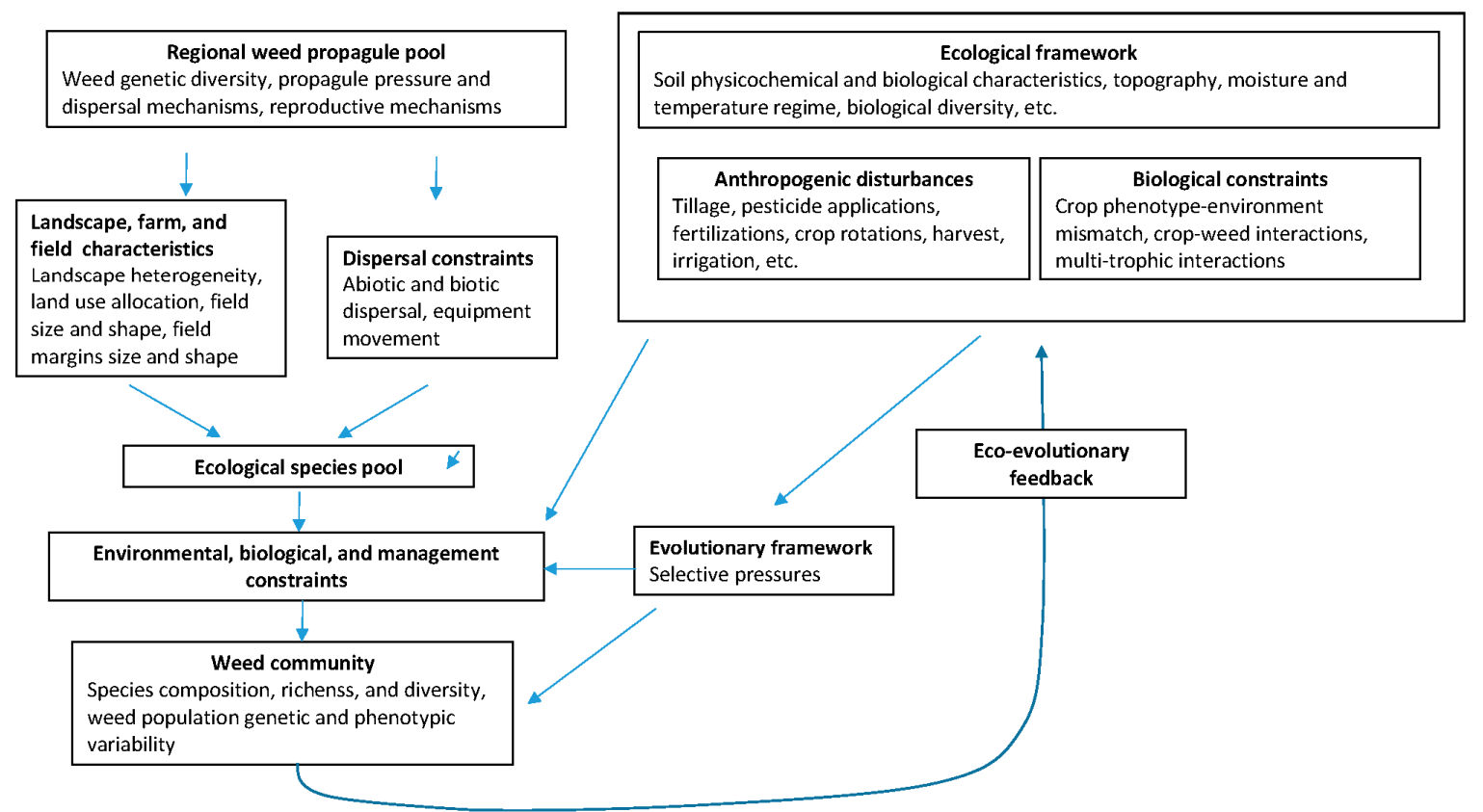

Figure 1. The eco-evolutionary conceptual framework determining the selective pressures determining the characteristic of the weed community and the resulting eco-evolutionary feedback. The left panel of this figure is adapted from Booth and Swanton, and Petit et al.

\section{Weed Science and Management: What Went Wrong?}

Modern weed science is a relatively new discipline that was born largely out of advances in chemistry that emerged following the Second World War and grew in close association with crop science, but lacks a theoretical underpinning rooted in evolutionary or ecological disciplines $[5,30]$. Since the early 1950s and following the discovery of 2,4-dichlorophenoxyacetic acid (2,4-D), synthetic herbicides have been at the foundation of both weed science research as well as the intensification and expansion of industrialized agriculture. Currently, an estimated 915,000 metric tons of herbicide active ingredients valued at US $\$ 15.5$ billion are used each year to control weeds worldwide [31]. In the US, the country with the largest number of cases of reported herbicide resistant biotypes, $97 \%$ of corn (Zea mays L.), $98 \%$ of soybean (Glycine max L.), and $61 \%$ of wheat (Triticum aestivum L.) crops are regularly treated with herbicides [32]. In both corn and soybean, the most frequently used herbicides represent just four herbicide site of actions [5-enolpyruvylshikimate-3-phosphate (EPSP) synthase inhibitors, photosystem II inhibitors (PPO) inhibitors, and seedling growth shoot inhibitors), while only site of actions dominate wheat systems acetolactate synthase (ALS) inhibitors and acetyl CoA carboxylase ACCase inhibitors)] [32]. Similarly, in Western Canada, 86\% of the area seeded in cereals and annual legumes, as well as $93 \%$ of the area seeded in oilseed crops, received at least one herbicide application in 2006 [33]. This approach to weed management has been characterized as a "ruthless fight to the last weed" [34] through the use of highly effective herbicides.

The unifying principles driving current the herbicide-based approach to weed management are: (1) the precautionary principle (use the most lethal treatment when in doubt about the threat); (2) rapid and effective response (management must be deadly); and (3) eradication expectation (the pest must be removed). These principles lead to the pursuit of "silver bullet" management tactics, an effective approach to secure yield and enhance farm-labor efficiency. Yet, the "silver bullet" paradigm has, over the long-term, consistently failed $[35,36]$ due to unintended but predictable eco-evolutionary consequences. By controlling greater than $90 \%$ of the weed flora within a farm field, herbicide applications impose strong selection for resistant weed biotypes [37]. Currently, more than 470 biotypes from 250 weed species are resistant to 160 of 281 different herbicides belonging to 23 of the 26 herbicide 
site of action groups [38]. Many of these resistant biotypes also withstand exposure to herbicides from different herbicide families targeting the same site of action, a phenomenon known as cross resistance. Furthermore, the alarming increase in weed biotypes resistant to herbicides targeting different sites of action, referred to as multiple resistance, has created major weed management challenges $[39,40]$. Concomitant with the loss of efficacy of some herbicides due to resistance, the availability of herbicide chemistries has been declining over the last 25 years due to environmental and human health concerns [41], lack of market and perceived profitability with older post-patent herbicides, and the absence of discovery of novel herbicide chemical families [42]. This trend was further reinforced with the development and wide-scale adoption of transgenic herbicide tolerant crop varieties, an approach that has dramatically simplified the agricultural landscape and increased selection for herbicide resistant biotypes.

Shaner and Beckie [33] provided a reflective review of failures and mistakes of weed control approaches centered on chemical solutions. This retrospective analysis identified several problem areas including the general lack of diversity in weed management, an unwillingness by weed scientists to conduct integrated and multidisciplinary research, a reluctance by extension specialists to provide complex recommendations to growers and for growers to accept difficult-to-implement solutions, and the short-term priorities of herbicide marketing and sales organizations determining recommendations rather than considering longer-term strategies for herbicide stewardship. While we agree with [33] that these factors play heavily into explaining why we have reached the current situation, we also believe that a major fault lies in the fact that weed research and education-and indeed weed science as a discipline-have largely failed to fully embrace an eco-evolutionary framework as a central tenet.

\section{How Did We Get Here? A Brief History of Pest Management}

Although not fully embraced by weed scientists, an evolutionary framework has been a cornerstone of other pest management disciplines since early observations of arthropods developing resistance to insecticides led to the establishment of the concept of integrated control [43] and pest management [44]. Indeed, in 1959, evolution was invoked by listing "genetic plasticity" of arthropods as a main reason for integrated control [43]. Despite this early call, development of the integrated pest management (IPM) framework in the early 1960s and 1970s further solidified the link between insecticide resistance management and ecology, but failed to fully embrace and eco-evolutionary perspective. For example, [45] stressed the importance of considering the "total ecosystem", even calling it a first principle of IPM, and [44] stated that pest management "was coined to emphasize the comprehensive nature of the approach, and to underline its preoccupation with ecological realities". It was further stated that IPM "strives to reduce pest status to tolerable levels by using methods that are effective, economically sound, and ecologically compatible" [46], and it was further stated that pest management should address, "(1) economic sustainability through minimizing the economic impact of pests; (2) ecological sustainability through employing management tactics so as to minimize selection pressure, and; (3) environmental sustainability through minimizing the impact of management on the environment" [47]. Despite these calls, the use of ecology as a central underpinning for pest management has been overlooked, which has led the effort to create a new paradigm, ecologically-based pest management (EBPM) [48]. Unfortunately, evolution's role has received relatively little attention and it was rarely discussed in developing applied pest management programs. For example, in his thorough review of the history of IPM, [48] uses the term "evolution" only twice, and both times this term is not employed in the context of biological evolution and pest management.

While most academic entomology and plant pathology departments or programs complement basic research grounded in ecological and evolutionary principles with the design of applied management practices, weed science has evolved closely associated with crop science but generally isolated from plant ecology and evolutionary biology departments [5]. This isolation has created a discipline focused on minimizing weed competitive interactions with genetically uniform crops instead 
of understanding how plant ecology and evolutionary principles can help guide weed management decisions. For example, a full 22 years after the link between evolution and integrated control was highlighted [43], the Weed Science Society of America held, to our knowledge, the first symposium on integrated management. The overarching goal of this symposium was to provide a basis for considering "weed control practice in the broader context of their interactions with other crop-production practices, management practices for other pests, ecosystems, social concerns, and the political setting" [49]. Sadly, while offering an advanced agenda and with approximately 30 unique cases of herbicide resistance already confirmed, ten occurring in the US [38], no presentation at the symposium addressed the issue of herbicide resistance.

Nearly a decade later, and in response to growing societal concerns over the impacts of herbicides on the environment, [50] articulated the concept of integrated weed management (IWM) through the use of multiple and complementary tactics specifically tailored to biological and ecological characteristics of agricultural weeds. Although there has been disagreement among weed scientists about the core concepts of IWM (reviewed in [51]), there is a formal recognition that it must consider the agroecological context within which weeds occur. This idea was further expanded by the "many little hammers" concept that weed populations can be managed through the integration of a concatenated set of control tactics and ecological interactions whose individual effects may be small and, therefore, weakly selective, but whose cumulative effects help reduce population growth and competition against crops [52]. More recently, academic reviews and empirical studies [51,53] have highlighted the importance of incorporating an IWM perspective in the design of best management practices to prevent weed spread and manage herbicide resistance. A common theme in these studies is the critical role that diversity, including diversification of management practices, plays in weed management. These studies, however, do not explicitly discuss the eco-evolutionary processes that could inform the development of more sustainable strategies to manage weeds.

Professional scientific societies have also failed to fully embrace an eco-evolutionary perspective. For example, the Weed Science Society of America (WSSA) and its sister regional organizations are non-profit societies promoting research, education, and awareness of weeds in managed and natural ecosystems [54]. The membership is primarily composed of academic and government researchers, as well as researchers employed by the pesticide manufacturing industry. Recently, the WSSA has been proactively addressing the issue of herbicide resistance through a number of new educational efforts on development and spread, identification and control, best management practices (BMPs), and the economic implications of resistant weeds [55]. Several WSSA symposia have also promoted a series of BMPs to foster the adoption of IWM practices [55]. However, despite the increased occurrence of herbicide resistance, most of the recommended BMPs have not changed substantively in several decades [56]. We believe much more effort must be directed to research and education around developing proactive weed management based on eco-evolutionary principles.

\section{The Doomed Marriage between Integrated Weed Management and Herbicide Resistance}

There are four major limitations of IWM being borne mainly out of societal and environmental concerns over herbicide use [50,57], rather than as an explicit strategy for minimizing herbicide resistance. First, because the foundational underpinnings of IWM are not explicitly grounded in eco-evolutionary theory, it is unlikely to be effective at preventing the evolution of herbicide-resistant weed populations. This is because herbicide resistance is not solely a function of the total quantity or environmental toxicity of the herbicides applied, but rather the biology, genetic diversity, and demography of individual weed populations and their temporal and spatial interactions with the cropping environment. An herbicide will rapidly select for a resistant weed population if the traits conferring resistance vary genetically, weed populations are large, and the herbicide has a high frequency of use. Hence, IWM must explicitly incorporate an eco-evolutionary perspective to develop a predictive assessment of how management practices could affect the evolution of herbicide resistance. In doing so, weed scientists should consider models that take into account the role of species 
reproduction systems, population size, propagule migration, and genetic variation to explain the rapid evolution that occurs after herbicide use [58]. Unfortunately, while mathematical models have become valuable tools to assess the response of weed populations to management practices $[59,60]$ or the invasive potential of introduced species [61], by not explicitly incorporating intra-population genetic variability they have limited ability to predict the evolutionary response of weed populations to intense selection imposed by weed control.

Second, by focusing principally on local weed populations (i.e., only the weeds present in a given field at one point in time), most IWM programs fail to explicitly consider the regional movement of herbicide resistant genes. For example, glyphosate-resistant Conyza canadensis (horseweed) first appeared on the Delmarva Peninsula on the East Coast of the US in 2000 [62]. Over the next 15 years, resistant $C$. canadensis evolved and spread through large areas of the southern corn belt and the Mid-Atlantic region and has recently been detected as far west as Montana and California [38]. C. canadensis is wind dispersed, and its seeds can transport herbicide resistance genes tens or hundreds of kilometers in a single dispersal event [63]. The spread of glyphosate resistant $C$. canadensis biotypes was further facilitated by the high degree of landscape uniformity due to the widespread adoption of glyphosate-resistant crops managed without tillage and reduced tillage fields that were maintained fallow between crops with glyphosate.

Third, IWM is increasingly being promoted primarily as a reactive strategy for managing weed populations, rather than as a proactive multi-tactical strategy. For example, the industry sector has focused its attention on early detection, monitoring, and mitigation of herbicide resistance through the implementation of IWM [64]. However, although many product labels include a paragraph or two on resistance management, and perhaps a paragraph on IWM, the information tends to be general rather than specific and usually recommends adding additional herbicides with different sites of action. The rotation or mixture of herbicides with different sites of action can help delay selection for herbicide-resistant weed biotypes $[65,66]$, but at the same time represents a strong selective force for non-target site resistance and, contrary to its goal, it may increase the occurrence of herbicide resistance via multiple independent mechanisms [57,67]. This is not unlike the situation arising from the widespread use of highly effective antibiotics in human health and agriculture, which has resulted in a global crisis of antimicrobial resistance, which is threatening the achievements of modern medicine [8].

Fourth, recently-proposed IWM technological advances have failed to explicitly consider the eco-evolutionary framework that drives the selection of herbicide resistance. For example, in response to the increasing prevalence of glyphosate-resistant weed biotypes, there has been increased interest in providing weed management solutions through the development of new transgenic crops stacked with herbicide resistant traits to auxinic herbicides, as well as to herbicides that inhibit acetolactate synthase (ALS), acetyl-CoA carboxylase (ACCase) and hydroxyphenylpyruvate dioxygenase (HPPD), stacked with glyphosate and/or glufosinate resistance [68]. This idea has been promoted as a sustainable approach to help manage selection for herbicide resistant weed biotypes, potentially reduce the use of herbicides, and decrease potential adverse effects on non-target organisms [69]. However, from an eco-evolutionary perspective, the approach of "stacking" or "pyramiding" herbicidal control tactics implies increasing the dimensionality of the selection pressure by layering one selective force on the top of another [26]. Eventually, "stacking" control tactics will select for multiple herbicide resistance [70,71] and the subsequent adoption of more environmentally damaging forms of weed management such as tillage, ultimately reducing some of the initial environmental benefits predicted by the introduction of multiple-herbicide resistant crops.

\section{Eco-Evolutionary Thinking and Weed Management}

Agricultural weeds can be conceived as a relatively recent ecological and evolutionary phenomenon, reflecting the response of native and introduced plant populations to the selective pressures imposed by agricultural practices. Paradoxically, while a goal of agriculture is to take 
advantage of the best crop genetics and available management options for the environmental conditions present in a specific field, the existing genetic variability occurring at the field level within weed populations and the selective pressure imposed by management practices results in the selection of specific locally-adapted weed species/biotypes. To minimize the impact of weeds on crop yield, agroecosystems are generally managed with a multitude of practices, such as tilling the soil to prepare the seedbed or planting no-till, repeated applications of synthetic fertilizers, use of herbicides, insecticides, and fungicides to ward off weeds, insect pests, and plant disease, and timely harvest to ensure maximum crop yield [72-74]. These anthropogenic disturbances represent major drivers that often occur on relatively short timescales and determine the setting where pest evolution occurs. For example, the selection and spread of herbicide resistant weed biotypes, as well as the novel selective pressures imposed by the alternative management tactics employed by farmers to control these resistant biotypes, represents one of the most striking real-time illustrations of rapid evolution $[5,6,75]$.

Previous research has evaluated the role that biotic and abiotic constraints, as well as landscape factors, play in determining the assembly trajectories of weed populations and communities [76,77]. Yet, the importance of eco-evolutionary processes in determining weed community dynamics is usually not considered. Thus, an eco-evolutionary approach should be at the forefront of a weed research agenda designed to develop more sustainable management systems. How do we develop an effective eco-evolutionary weed management strategy? The following five complementary concepts could help us reach the goal of undermining the adaptation of herbicide resistant weeds to the novel environments created by highly selective herbicides (Table 1).

First, weed scientists must recognize that evolution occurs within crop fields at ecological time scales and is rooted in the inherent genotypic and phenotypic variation that exists in all weed populations. This variation is, in part, the product of regional and local migration processes as well as genetic drift and random mutations that occur at rates that may appear extremely low; yet, when considered relative to the number of individuals (e.g., seeds and other propagules) that are present across the agricultural landscape, it can actually be high [26,78]. This variation occurs in the absence of the selective pressure imposed by any particular management practice, but is "revealed" when the mutant individual is exposed to the control tactic for which the mutation confers resistance $[79,80]$. If successful, this biotype will modify the ecological characteristics of the systems (Figure 1). Thus, an eco-evolutionarily stable weed management strategy designed to prevent the selection for herbicide resistant biotypes should strive to jointly slow unwanted selection of herbicide resistant biotypes, as well as reduce the crop phenotype-environment mismatch (i.e., the discrepancy between local phenotype and the optimum phenotype for a set of environmental conditions, a metric of potential maladaptation) [8]. Specific management practices to achieve these goals should aim at maintaining susceptible weed genotypes across the landscape and enhancing temporal variation in selection by means of rotating crops and the associated weed management tactic employed. Tactics, such as diversified rotation and appropriated crop sequencing, use of cover crops, intercropping, and appropriated use of soil amendments should be assembled to complement one another [52] and reduce selection pressures through programs that enhance crop competition and increase weed suppression $[81,82]$. 
Table 1. Main concepts and proposed actions to design an eco-evolutionary weed management program aimed at reducing the selective pressures towards the selection of herbicide-resistant biotypes.

\begin{tabular}{|c|c|}
\hline Concepts & Actions \\
\hline $\begin{array}{l}\text { Spatiotemporal framework: evolution occurs at small } \\
\text { spatial (within crop fields) and time scales (within season) }\end{array}$ & $\begin{array}{l}\text { Maintain susceptible weed genotypes across the landscape. } \\
\text { Augment the temporal and spatial variation of selection pressures by diversifying crop rotation and } \\
\text { management tactics. } \\
\text { Minimize the phenotype-environment mismatch of the cropping systems by using locally adapted and } \\
\text { competitive crop varieties. }\end{array}$ \\
\hline $\begin{array}{l}\text { Genetic variability: the probability of a resistant mutant } \\
\text { occurring in a population is directly related to its size }\end{array}$ & $\begin{array}{l}\text { Complement reactive weed management practices with predictive tools. } \\
\text { Incorporate intra- and inter-population genetic variability into demographic models. }\end{array}$ \\
\hline $\begin{array}{l}\text { Landscape and regional implications: the selection of } \\
\text { herbicide resistant biotypes transcends any one farm }\end{array}$ & $\begin{array}{l}\text { Since weed propagules can travel large distances either via nature (i.e., wind) or due to anthropogenic forces } \\
\text { (contaminated grain and equipment), local networks of famers should coordinate actions to prevent the spread of } \\
\text { herbicide resistant biotypes. } \\
\text { USDA-APHIS and State Department of Agriculture must collaborate to develop state and federal weed laws } \\
\text { and procedures that better monitor interstate movement of noxious and obnoxious weed seeds and } \\
\text { vegetative propagules. } \\
\text { Societal pressures together with local, state, or federal regulations should mandate the maximum use of specific } \\
\text { herbicide active ingredients or a resistant crop trait within a region. } \\
\text { Take advantage of genetic tool and dispersal models to design agricultural landscapes that minimize the spread } \\
\text { of undesired genotypes. }\end{array}$ \\
\hline $\begin{array}{l}\text { Societal pressures, incentives, and regulations: } \\
\text { incentives in the form of positive or negative } \\
\text { reinforcement can help the adoption of } \\
\text { eco-evolutionary practices }\end{array}$ & $\begin{array}{l}\text { Registration of new crop biotechnologies that involve herbicides should explicitly address the management of } \\
\text { herbicide resistance. } \\
\text { Design programs to disincentive the overreliance on one specific technology package and encourage the adoption } \\
\text { of ecologically based practices. } \\
\text { Utilize fees collected from these programs to develop and deliver an ecological-based weed management } \\
\text { program aimed at reducing herbicide selective pressures. } \\
\text { Develop environmental payment structure/stewardship programs that connects IWM to broader environmental } \\
\text { goals such as reducing the selective pressured towards undesired genotypes. } \\
\text { Consider the suite of ecosystem functions provided by cropping systems when developing incentive policies, } \\
\text { educational activities, and in developing research funding priorities for federal and state competitive } \\
\text { research programs. }\end{array}$ \\
\hline $\begin{array}{l}\text { Risk assessment: utilize the paradigm of risk analysis to } \\
\text { formally incorporate an eco-evolutionary perspective into } \\
\text { IWM strategies }\end{array}$ & $\begin{array}{l}\text { Jointly consider the inherent ability of the herbicide to select for resistance and the amount of contact between the } \\
\text { herbicide and the weed population to assess the risk of resistance. } \\
\text { Develop risk models that include weed phenotypic variation, density of weeds, total population of weeds, } \\
\text { seedbank characteristics, treated area, frequency of application, landscape heterogeneity, and agronomic factors. }\end{array}$ \\
\hline
\end{tabular}


Second, an eco-evolutionarily stable weed management program should recognize that the probability of a resistant mutant occurring in a population is directly related to its size [83]. For example, if herbicide resistance is conferred by a single, nuclear, completely-dominant gene with a mutation rate of $1 \times 10^{-8}$ and a population density of 500 individuals $\cdot \mathrm{m}^{-2}$, the probability of there being at least one resistant individual within a 30 -ha field never exposed to the herbicide is $95 \%$, but precipitously drops to $26 \%$ if population density is 50 individuals $\cdot \mathrm{m}^{-2}$ and is only $0.6 \%$ if weed density is 1 individual $\cdot \mathrm{m}^{-2}[37,78]$. To minimize the selection of these mutant biotypes, weed managers should complement purely reactive practices, such as pre-emergence herbicide applications with the development and use of predictive tools. Weed population dynamics modeling provides valuable insight to predict the short-, mid-, and long-term responses of weed biotypes to management inputs. While the majority of such models include biological and ecological concepts, they should formally incorporate intra- and inter-population genetic variability to provide viable predictive tools that could help land managers make informed management decisions [5]. For example, it was demonstrated that allowing a proportion of herbicide susceptible individuals to remain in the field may represent a viable option to reduce the spread of herbicide resistance, assuming the resistant allele carries some type fitness penalty or populations are spatially defuse [83].

Third, farmers need to acknowledge that the selection of herbicide resistant biotypes transcends any one farm. Traditionally, weed management decisions are made at the individual field level. Yet, propagule dispersal can be highly influenced by the interactions between fields, farms, and landscape-scale spatial complexity [77]. While few examples exist where local networks help famers coordinate actions to manage pests [84], management strategies, community outreach, and regulatory oversight should emphasize the need for landscape-level coordination of weed management. These guidelines should focus on spatio-temporally explicit and species-specific area-wide management plans [69,85], and mandate the maximum use of specific herbicide active ingredients or a resistant crop trait within a region. As an example, an empirical model predicted that a heavy infestation of C. canadensis in a single field could spread to tens to hundreds of surrounding farms [86]. However, an area-wide management plan that reduces suitable habitat for resistant $C$. canadensis (e.g., perennial alfalfa), increases plant mortality, and reduces the selection pressure for resistant genes has the greatest impact on reducing the spread of herbicide resistance [87]. Genetic tools can be used to inform management at the landscape-scale in order to minimize the spread of undesired genotypes. For example, by utilizing microsatellite markers, [88] determined the existence of multiple independent origins of glyphosate-resistant C. canadensis in California and proposed regionally-coordinated strategies to slow or prevent the evolution and spread of herbicide resistant biotypes.

Fourth, incentives in the form of positive or negative reinforcement to help the adoption of eco-evolutionary practices are warranted. Mortensen and colleagues [70] recommended that regulatory agencies, such as the US EPA, require that registration of new transgene-herbicide crop combinations and by extension all new crop biotechnologies that involve herbicides, explicitly address herbicide resistant weed management. Similarly, it was suggested that fees directly connected to the sale of herbicide resistant seed or associated herbicides could provide a disincentive for overreliance on this technology package and help encourage the adoption of more ecologically based practices [57]. Yet, care should be taken so that this fees do not incentive the use of below-label rates as this practice has been associated with the selection of herbicide resistance. Fees could be used, in turn, for public and private research and education on the importance of incorporating an eco-evolutionary perspective in herbicide resistance prevention and management. Incentives could be fostered by government agencies and industry to conserve critical herbicide mode of actions as a means to encourage adoption of best practices and encourage the replacement of monoculture cropping with diverse rotations [55]. In this context, maximizing short-term net economic returns should no longer be the leading aspect driving producer decisions, but one of the many outcomes of their enterprise. To achieve this goal, industry and government incentives should consider all ecosystem services provided by evolutionarily-stable agroecosystems. 
Finally, an approach to incorporate an eco-evolutionary perspective more formally into IWM strategies is to leverage the paradigm of risk analysis. Under the umbrella of risk analysis reside the concepts of risk, risk perception, risk assessment, risk communication, and risk management $[89,90]$. A few examples relevant to agricultural and biological risk include introduction risks by non-native species [91,92], establishment risks by non-native species [61,93], environmental risks of established invasive plant species [94], non-target organism risks from pesticide applications [95-97], risk of leaving weeds below economic thresholds [83], and selecting for glyphosate-resistant weed biotypes [98]. Depending on the risk of interest, risk can be defined as a function of effect and exposure, or more simply how bad multiplied by how often. For example, the risk of evolution of weed resistance to an herbicide depends on the amount of additive genetic variation in resistance, but also on the selection pressure, which is determined by the inherent ability of the herbicide to select for resistance and the amount of contact between the herbicide and the weed population. Risk assessment models based on eco-evolutionary perspectives could formally incorporate aspects from our previous recommendations (see above) to arrive at probabilities for herbicide resistance. For example, input variables for a resistance risk model could include phenotypic variation, weed density, and reproduction mechanisms, seedbank characteristics, treated area, frequency of application, landscape heterogeneity, and agronomic factors. These approaches can be used not only for estimating the risk of herbicide resistance, but also for estimating how risk might be altered by the various management strategies discussed above. For example, how would the risk change with landscape-level coordination to ensure that minimizing weed densities at an individual crop-fields are not threatened by the application of a single selective agent across a large spatial area or over multiple consecutive growing seasons?

\section{Conclusions}

In a recent review [99], it was argued that although knowledge exists to advance ecologically-based weed management programs, adoption by farmers has been limited mainly due to inappropriate government policies, lack of market mechanisms, and a scarcity of social infrastructure to influence learning, decision-making, and actions by farmers. While we acknowledge from the beginning that the implementation of eco-evolutionary weed management could represent additional technical and intellectual hurdles for farmers and land managers, we believe that the environmental, economic, and social challenges of herbicide resistance require agriculturalists to collectively re-think our approach to weed management [70]. Indeed, it was the societal decision of maximizing the simplicity of weed management practices through the recurrent applications of a few very effective herbicides that resulted in the continuous increase in the abundance and spread of herbicide resistant biotypes.

Designing agroecosystems in the context of applied eco-evolutionary biology could help agronomists, weed scientists, and farmers solve many of the global challenges agricultural production faces, including herbicide resistance, but spanning to climate change and environmental degradation. Genetic and environmental manipulation can help farmers improve yields and crop quality by selecting specific crop types, crop rotations, and management tactics that minimize crop phenotype-environment mismatch in their local environments. In the specific case of herbicide resistance, and beyond the five specific complementary tactics described above, weed scientists should take advantage of the lessons learned not only by entomologists in their quest to manage insecticide resistance, but from human health professionals assessing approaches to minimize the threat of microbial resistance. Following the example of human health specialists, weed scientists need to question if their current management practices are evolutionarily stable and consider societal pressures to develop alternative management practices. By integrating weed biology, ecology, and evolution, new approaches to weed management must be multi-disciplinary in nature [5] and should consider societal dimensions of adopting alternative management practices.

Growing concerns about the need to balance weed management and food production with biodiversity and natural resources conservation has led to an increased interest to reconsider the 
weed science research agenda, including the explicit inclusion of an eco-evolutionary perspective [6]. The potential benefits of developing cropping systems supported on ecological and evolutionary principles are numerous and range from providing the functions necessary for sustained production including nutrient cycling, pollination, pest suppression, and detoxification of agrichemicals to reducing the selective pressure towards the selection of herbicide resistant biotypes. Ultimately, the farmer is responsible for implementing practices and conflict exists between individual and societal priorities. Education and regulatory efforts should be developed in conjunction with scientific advancements to respond to the eco-evolutionary imperative of revisiting weed management in the midst of an herbicide resistance crisis.

Acknowledgments: We would like to thank the United States Department of Agriculture, National Institute of Food and Agriculture (USDA NIFA) for its financial support.

Author Contributions: Fabian D. Menalled, Robert K. D. Peterson, and Richard G. Smith, and William S. Curran critically reviewed existing literature and wrote all sections of this manuscript. David J. Páez and Bruce D. Maxwell reviewed the manuscript and contributed to the eco-evolutionary section of this work.

Conflicts of Interest: The authors declare no conflict of interest.

\section{References}

1. Dobzhansky, T. Nothing in biology makes sense except in the light of evolution. Am. Biol. Teach. 1973, 35, 125-129. [CrossRef]

2. Darwin, C. On the Origin of Species by Natural Selection; Murray: London, UK, 1859.

3. Antolin, M.F.; Herbers, J.M. Perspective: Evolution's struggle for existence in America's public schools. Evolution 2001, 55, 2379-2388. [CrossRef] [PubMed]

4. Thrall, P.H.; Oakeshott, J.G.; Fitt, G.; Southerton, S.; Burdon, J.J.; Sheppard, A.; Russell, R.J.; Zalucki, M.; Heino, M.; Denison, R.F. Evolution in agriculture: The application of evolutionary approaches to the management of biotic interactions in agro-ecosystems. Evol. Appl. 2011, 4, 200-215. [CrossRef] [PubMed]

5. Neve, P.; Vila-Aiub, M.; Roux, F. Evolutionary-thinking in agricultural weed management. New Phytol. 2009, 184, 783-793. [CrossRef] [PubMed]

6. Neve, P.; Busi, R.; Renton, M.; Vila-Aiub, M.M. Expanding the eco-evolutionary context of herbicide resistance research. Pest Manag. Sci. 2014, 70, 1385-1393. [CrossRef] [PubMed]

7. Carroll, S.; Kinnison, M.T.; Bernatchez, L. In light of evolution: Interdisciplinary challenges in food, health, and the environment. Evol. Appl. 2011, 4, 155-158. [CrossRef] [PubMed]

8. Carroll, S.P.; Jorgensen, P.S.; Kinnison, M.T.; Bergstrom, C.T.; Denison, R.F.; Gluckman, P.; Smith, T.B.; Strauss, S.Y.; Tabashnik, B.E. Applying evolutionary biology to address global challenges. Science 2014, 346, 1245993. [CrossRef] [PubMed]

9. Hutchinson, G.E. The Ecological Theater and the Evolutionary Play; Yale University Press: New Haven, CT, USA, 1965.

10. Ellner, S.P. Rapid evolution: From genes to communities, and back again? Funct. Ecol. 2013, 27, 1087-1099. [CrossRef]

11. Hairston, N.G.; Ellner, S.P.; Geber, M.A.; Yoshida, T.; Fox, J.A. Rapid evolution and the convergence of ecological and evolutionary time. Ecol. Lett. 2005, 8, 1114-1127. [CrossRef]

12. Hendry, A.P.; Kinnison, M.T. Perspective: The pace of modern life: Measuring rates of contemporary microevolution. Evolution 1999, 53, 1637-1653. [CrossRef]

13. Reznick, D.A.; Bryga, H.; Endler, J.A. Experimentally induced life-history evolution in a natural population. Nature 1990, 346, 357-359. [CrossRef]

14. Grant, P.R.; Grant, B.R. Unpredictable evolution in a 30-year study of Darwin's finches. Science 2002, 296, 707-711. [CrossRef] [PubMed]

15. Antonovics, J. The input from population genetics: “The new ecological genetics". Syst. Bot. 1976, 1, $233-245$. [CrossRef]

16. Pimentel, D. Animal population regulation by genetic feedback mechanism. Am. Nat. 1961, 95, 65-79. [CrossRef] 
17. Elderd, B.D.; Dushoff, J.; Dwyer, G. Host-Pathogen Interactions, Insect outbreaks, and natural selection for disease resistance. Am. Nat. 2008, 172, 829-842. [CrossRef] [PubMed]

18. Duffy, M.A.; Sivars-Becker, L. Rapid evolution and ecological host-parasite dynamics. Ecol. Lett. 2007, 10, 44-53. [CrossRef] [PubMed]

19. Yoshida, T.; Ellner, S.P.; Jones, L.E.; Bohannan, B.J.M.; Lenski, R.E.; Hairston, N.G., Jr. Cryptic population dynamics: Rapid evolution masks trophic interactions. PLoS Biol. 2007, 5, 1868-1879. [CrossRef] [PubMed]

20. Yoshida, T.; Jones, L.E.; Ellner, S.P.; Fussmann, G.F.; Hairston, N.G. Rapid evolution drives ecological dynamics in a predator-prey system. Nature 2003, 424, 303-306. [CrossRef] [PubMed]

21. Abrams, P.A.; Matsuda, H. Prey adaptation as a cause of predator-prey cycles. Evolution 1997, 51, 1742-1750. [CrossRef]

22. Schreiber, S.J.; Buerger, R.; Bolnick, D.I. The community effects of phenotypic and genetic variation within a predator population. Ecology 2011, 92, 1582-1593. [CrossRef] [PubMed]

23. Fussmann, G.F.; Loreau, M.; Abrams, P.A. Eco-evolutionary dynamics of communities and ecosystems. Funct. Ecol. 2007, 21, 465-477. [CrossRef]

24. Coulson, T.; Benton, T.G.; Lundberg, P.; Dall, S.R.X.; Kendall, B.E. Putting evolutionary biology back in the ecological theatre: A demographic framework mapping genes to communities. Evol. Ecol. Res. 2006, 8, 1155-1171.

25. Nesse, R.M.; Bergstrom, C.T.; Ellison, P.T.; Flier, J.S.; Gluckman, P.; Govindaraju, D.R.; Niethammer, D.; Omenn, G.S.; Perlman, R.L.; Schwartz, M.D.; et al. Making evolutionary biology a basic science for medicine. Proc. Nat. Acad. Sci. USA 2010, 107, 1800-1807. [CrossRef] [PubMed]

26. Hendry, A.P.; Kinnison, M.T.; Heino, M.; Day, T.; Smith, T.B.; Fitt, G.; Bergstrom, C.T.; Oakeshott, J.; Jorgensen, P.S.; Zalucki, M.P.; et al. Evolutionary principles and their practical application. Evol. Appl. 2011, 4, 159-183. [CrossRef] [PubMed]

27. Schoener, T.W. The newest synthesis: Understanding the interplay of evolutionary and ecological dynamics. Science 2011, 331, 426. [CrossRef] [PubMed]

28. Loeuille, N.; Barot, S.; Georgelin, E.; Kylafis, G.; Lavigne, C. Eco-evolutionary dynamics of agricultural networks: Implications for sustainable management. Adv. Ecol. Res. 2013, 49, 339-435.

29. Keren, I.N.; Menalled, F.D.; Weaver, D.K.; Robison-Cox, J.F. Interacting agricultural pests and their effect on crop yield: Application of a Bayesian decision theory approach to the joint management of Bromus tectorum and Cephus cinctus. PLoS ONE 2015. [CrossRef] [PubMed]

30. Zimdahl, R.L. Weed Science-A Plea for Thought-Revisited; Springer Brief in Agriculture: Dordrecht, The Netherlands, 2012; p. 73.

31. Grube, A.; Donaldson, D.; Kiely, T.; Wu, L. Pesticides Industry Sales and Usage-2006 and 2007 Market Estimates; U.S. Environmental Protection Agency: Washington, DC, USA, 2011. Available online: https:/ / nepis.epa.gov/Exe/ZyPDF.cgi/P100A8DN.PDF?Dockey=P100A8DN.PDF\#_ga=1.47126055. 1632740713.1445374245 (accessed on 13 October 2016).

32. North American Spine Society (NASS). Agricultural Chemical Use Program. United States Department of Agriculture. Available online: http://www.nass.usda.gov/Surveys/Guide_to_NASS_Surveys/Chemical_ Use/index.php (accessed on 11 October 2016).

33. Shaner, D.L.; Beckie, H.J. The future for weed control and technology. Pest Manag. Sci. 2014, 70, 1329-1339. [CrossRef] [PubMed]

34. Zimdahl, R.L. Who are you and where are you going. Weed Tech. 1994, 8, 388-391.

35. Lewis, W.J.; vanLenteren, J.C.; Phatak, S.C.; Tumlinson, J.H. A total system approach to sustainable pest management. Proc. Nat. Acad. Sci. USA 1997, 94, 12243-12248. [CrossRef] [PubMed]

36. Mortensen, D.A.; Bastiaans, L.; Sattin, M. The role of ecology in the development of weed management systems: An outlook. Weed Res. 2000, 40, 49-62. [CrossRef]

37. Jasieniuk, M.; Brûlé-Babel, A.L.; Morrison, I.N. The evolution and genetics of herbicide resistance in weeds. Weed Sci. 1996, 44, 176-193. [CrossRef]

38. Heap, I. International Survey of Herbicide Resistant Weeds. Available online: http://www.weedscience. com/summary/home.aspx (accessed on 13 October 2016).

39. Hall, L.M.; Holtum, J.A.M.; Powles, S.B. Mechanisms responsible for cross resistance and multiple resistance. In Herbicide Resistance in Plants: Biology and Biochemistry; Powles, S.B., Holtum, J.A.M., Eds.; Lewis Publishers: Boca Raton, FL, USA, 1994; pp. 243-261. 
40. Lehnhoff, E.A.; Keith, B.K.; Dyer, W.E.; Peterson, R.K.; Menalled, F. Multiple herbicide resistance in wild oat and impacts on physiology, germinability, and seed production. Agron. J. 2013, 105, 854-862. [CrossRef]

41. Stoate, C.; Boatman, N.D.; Borralho, R.J.; Carvalho, C.R.; de Snoo, G.R.; Eden, P. Ecological impacts of arable intensification in Europe. J. Environ. Manag. 2001, 63, 337-365. [CrossRef]

42. Duke, S.O. Why have no new herbicide modes of action appeared in recent years? Pest Manag. Sci. 2012, 68, 505-512. [CrossRef] [PubMed]

43. Stern, V.M.; Smith, R.; van Bosch, R.; Hagen, K.S. The integration of chemical and biological control of the spotted alfalfa aphid. The integrated control concept. Field experiments on the effects of insecticides. Impact of commercial insecticide treatments. Hilgardia 1959, 29, 81-101. [CrossRef]

44. Geier, P.W. Management of insect pests. Ann. Rev. Entomol. 1966, 11, 471-490. [CrossRef] [PubMed]

45. Smith, R.F. Integration of biological and chemical control. Introduction and principles. Bull. Entomol. Soc. Am. 1962, 8, 188-189. [CrossRef]

46. Pedigo, L.P. Entomology and Pest Management; Macmillan Publishing Company: New York, NY, USA, 1989.

47. Higley, L.G.; Wintersteen, W.K. Thresholds and environmental quality. In Economic Thresholds for Integrated Pest Management; Higley, L., Pedigo, L., Eds.; University of Nebraska Press: Lincoln, Nebraska, 1996; pp. 249-274.

48. Kogan, M. Integrated pest management: Historical perspectives and contemporary developments. Ann. Rev. Entomol. 1998, 43, 243-270. [CrossRef] [PubMed]

49. Miller, G.R. Symposium on integrated weed management systems. Technology for crop production and protection held at the Annual Meeting of Weed Science Society of America. Las Vegas, Nevada, USA FEB. 19 1981. Weed Sci. 1982, 30 (Suppl. S1), 2.

50. Swanton, C.J.; Weise, S.F. Integrated weed management. The rationale and approach. Weed Tech. 1991, 5 , 657-663.

51. Owen, M.D. K.; Beckie, H.J.; Leeson, J.Y.; Norsworthy, J.K.; Steckel, L.E. Integrated pest management and weed management in the United States and Canada. Pest Manag. Sci. 2015, 71, 357-376. [CrossRef] [PubMed]

52. Liebman, M.; Gallandt, E.R. Many little hammers: Ecological management of crop-weed interactions. In Ecology in Agriculture; Jackson, L.E., Ed.; Academic: San Diego, CA, USA, 1997; pp. 291-343.

53. Norsworthy, J.K.; Ward, S.M.; Shaw, D.R.; Llewellyn, R.S.; Nichols, R.L.; Webster, T.M.; Bradley, K.W.; Frisvold, G.; Powles, S.B.; Burgos, N.R.; et al. Reducing the Risks of Herbicide Resistance: Best Management Practices and Recommendations. Weed Sci. 2012, 60, 31-62. [CrossRef]

54. Weed Science Society of America (WSSA). Available online: http://wssa.net/about-us/ (accessed on 8 December 2016).

55. Weed Science Society of America (WSSA). WSSA Infographics on Herbicide Resistance Management. Available online: http://wssa.net/herbicide-resistance/wssa-infographics-on-herbicide-resistance-management/ (accessed on 8 December 2016).

56. Owen, M.D.K. Diverse approaches to herbicide-resistant weed management. Weed Sci. 2016, 64, 570-584. [CrossRef]

57. Liebman, M.; Mohler, C.L.; Staver, C.P. Ecological Management of Agricultural Weeds; Cambridge University Press: Cambridge, UK, 2001.

58. Delye, C.; Jasieniuk, M.; Le Corre, V. Deciphering the evolution of herbicide resistance in weeds. Trends Genet. 2013, 29, 649-658. [CrossRef] [PubMed]

59. Davis, A.S.; Dixon, P.M.; Liebman, M. Using matrix models to determine cropping system effects on annual weed demography. Ecol. Appl. 2004, 14, 655-668. [CrossRef]

60. Westerman, P.; Liebman, M.; Menalled, F.D.; Heggenstaller, A.H.; Hartzler, R.G.; Dixon, P.M. Are many little hammers effective?-Velvetleaf (Abutilon theophrasti) population dynamics in two- and four-year crop rotation systems. Weed Sci. 2005, 53, 382-392. [CrossRef]

61. Davis, P.B.; Menalled, F.D.; Peterson, R.K.D.; Maxwell, B.D. Refinement of weed risk assessments for biofuels using Camelina sativa as a model species. J. Appl. Ecol. 2011, 48, 989-997. [CrossRef]

62. VanGessel, M.J. Glyphosate-resistant horseweed from Delaware. Weed Sci. 2001, 49, 703-705. [CrossRef]

63. Dauer, J.T.; Mortensen, D.A.; Vangessel, M.J. Temporal and spatial dynamics of long-distance Conyza canadensis seed dispersal. J. Appl. Ecol. 2007, 44, 105-114. [CrossRef]

64. Soteres, J.K.; Peterson, M.A. Industry views of monitoring and mitigation of herbicide resistance. Weed Sci. 2015, 63, 972-975. [CrossRef] 
65. Beckie, H.J.; Reboud, X. Selecting for weed resistance: Herbicide rotation and mixture. Weed Tech. 2009, 23, 363-370. [CrossRef]

66. Evans, J.A.; Tranel, P.J.; Hager, A.G.; Schutte, B.; Wu, C.; Chatham, L.A.; Davis, A.S. Managing the evolution of herbicide resistance. Pest Manag. Sci. 2016, 72, 74-80. [CrossRef] [PubMed]

67. Neve, P.; Sadler, J.; Powles, S.B. Multiple herbicide resistance in a glyphosate-resistant rigid ryegrass (Lolium rigidum) population. Weed Sci. 2004, 52, 920-928. [CrossRef]

68. Duke, S.O. Perspectives on transgenic, herbicide-resistant crops in the United States almost 20 years after introduction. Pest Manag. Sci. 2015, 71, 652-657. [CrossRef] [PubMed]

69. Lombardo, L.; Coppola, G.; Zelasco, S. New technologies for insect-resistant and herbicide-tolerant plants. Trends Biotech. 2016, 34, 49-57. [CrossRef] [PubMed]

70. Mortensen, D.A.; Egan, J.F.; Maxwell, B.D.; Ryan, M.R.; Smith, R.G. Navigating a Critical Juncture for Sustainable Weed Management. Bioscience 2012, 62, 75-84. [CrossRef]

71. Egan, J.F.; Maxwell, B.D.; Mortensen, D.A.; Ryan, M.R.; Smith, R.G. 2,4-Dichlorophenoxyacetic acid (2,4-D)-resistant crops and the potential for evolution of 2,4-D-resistant weeds. Proc. Natl. Acad. Sci. USA 2011, 108, E37. [CrossRef] [PubMed]

72. Landis, D.A.; Menalled, F.D.; Costamagna, A.C.; Wilkinson, T.K. Manipulating plant resources to enhance beneficial arthropods in agricultural landscapes. Weed Sci. 2005, 53, 902-908. [CrossRef]

73. Smith, R.G.; Menalled, F.D.; Robertson, G.P. Temporal yield variability under conventional and alternative management systems. Agron. J. 2007, 99, 1629-1634. [CrossRef]

74. Smith, R.G. A succession-energy framework for reducing non-target impacts of annual crop production. Agric. Syst. 2015, 133, 14-21. [CrossRef]

75. Baucom, R.S. The remarkable repeated evolution of herbicide resistance. Am. J. Bot. 2016, 103, $181-183$. [CrossRef] [PubMed]

76. Booth, B.D.; Swanton, C.J. Assembly theory applied to weed communities. Weed Sci. 2002, 50, 2-13. [CrossRef]

77. Petit, S.; Alignier, A.; Colbach, N.; Joannon, A.; Le Coeur, D.; Thenail, C. Weed dispersal by farming at various spatial scales. A review. Agric. Sustain. Dev. 2013, 33, 205-217. [CrossRef]

78. Maxwell, B.D.; Mortimer, A.M. Selection for herbicide resistance. Herbic. Resist. Plants Biol. Biochem. 1994, 1, 205-212.

79. Hoffmann, A.A.; Merila, J. Heritable variation and evolution under favourable and unfavourable conditions. Trends Ecol. Evol. 1999, 14, 96-101. [CrossRef]

80. McGuigan, K.; Sgro, C.M. Evolutionary consequences of cryptic genetic variation. Trends Ecol. Evol. 2009, 24, 305-311. [CrossRef] [PubMed]

81. Maxwell, B.D.; O’Donovan, J.T. Understanding weed-crop interactions to manage weed problems. In Non Chemical Weed Management: Principles, Concepts and Technology; CAB International/North America Office: Cambridge, MA, USA, 2007; pp. 17-33.

82. Weiner, J.; Andersen, S.B.; Wille, W.K.M.; Griepentrog, H.W.; Olsen, J.M. Evolutionary Agroecology: The potential for cooperative, high density, weed-suppressing cereals. Evol. Appl. 2010, 3, 473-479. [CrossRef] [PubMed]

83. Maxwell, B.D. Weed thresholds-The space component and considerations for herbicide resistance. Weed Tech. 1992, 6, 205-212.

84. Warner, K.D. Extending agroecology: Grower participation in partnerships is key to social learning. Renew. Agric. Food Sys. 2006, 21, 84-94. [CrossRef]

85. Ervin, D.; Jussaume, R. Integrating social science into managing herbicide-resistant weeds and associated environmental impacts. Weed Sci. 2014, 62, 403-414. [CrossRef]

86. Dauer, J.T.; Luschei, E.C.; Mortensen, D.A. Effects of landscape composition on spread of an herbicide-resistant weed. Landsc. Ecol. 2009, 24, 735-747. [CrossRef]

87. Dauer, J.T.; Mortensen, D.A.; Luschei, E.C.; Isard, S.A.; Shields, E.; Van-Gessel, M.J. Conyza canadensis seed ascent in the lower atmosphere. Agric. For. Meteorol. 2009, 149, 526-534. [CrossRef]

88. Okada, M.; Hanson, B.D.; Hembree, K.J.; Peng, Y.; Shrestha, A.; Stewart, C.N., Jr.; Wright, S.D.; Jasieniuk, M. Evolution and spread of glyphosate resistance in Conyza canadensis in California. Evol. Appl. 2013, 6, 761-777. [CrossRef] 
89. National Research Council. Risk Assessment in the Federal Government: Managing the Process; National Academy Press: Washington, DC, USA, 1983.

90. National Research Council. Understanding Risk: Informing Decisions in a Democratic Society; National Academy Press: Washington, DC, USA, 1996.

91. Intergovernmental Panel on Climate Change. International Standards for Phytosanitary Management (ISPM) 2: Framework for Pest Risk Analysis; Food and Agriculture Organization of the United Nations: Rome, Italy, 2016; p. 16.

92. Pheloung, P.C.; Williams, P.A.; Halloy, S.R. A weed risk assessment model for use as a biosecurity tool evaluating plant introductions. J. Environ. Manag. 1999, 57, 239-251. [CrossRef]

93. Schleier, J.J., III; Sing, S.E.; Peterson, R.K.D. Regional ecological risk assessment for the introduction of Gambusia affinis (western mosquitofish) into Montana watersheds. Biol. Invasions 2008, 10, 1277-1287. [CrossRef]

94. Sing, S.E.; Peterson, R.K.D. Assessing environmental risks for established invasive weeds: Dalmatian (Linaria dalmatica) and yellow (L. vulgaris) toadflax in North America. Int. J. Environ. Res. Public Health 2011, 8, 2828-2853. [CrossRef] [PubMed]

95. Davis, R.S.; Peterson, R.K.D.; Macedo, P.A. An ecological risk assessment for insecticides used in adult mosquito management. Int. Environ. Assess. Manag. 2007, 3, 373-382. [CrossRef]

96. Peterson, R.K.D. Comparing ecological risks of pesticides: The utility of a Risk Quotient ranking approach across refinements of exposure. Pest Manag. Sci. 2006, 62, 46-56. [CrossRef] [PubMed]

97. Peterson, R.K.D.; Hulting, A.N.G. A comparative ecological risk assessment for herbicides used on spring wheat: The effect of glyphosate when used within a glyphosate-tolerant wheat system. Weed Sci. 2004, 52, 834-844. [CrossRef]

98. Stanton, R.A.; Pratley, J.E.; Hudson, D.; Dill, G.M. A risk calculator for glyphosate resistant in Lolium rigidum (Gaud.). Pest Manag. Sci. 2008, 64, 402-408. [CrossRef] [PubMed]

99. Liebman, M.; Baraibar, B.; Buckley, Y.; Childs, D.; Christensen, S.; Cousens, R.; Eizenberg, H.; Heijting, S.; Loddo, D.; Merotto, A.; et al. Ecologically sustainable weed management: How do we get from proof-of-concept to adoption? Ecol. Appl. 2016, 26, 1352-1369. [CrossRef] [PubMed]

(C) 2016 by the authors; licensee MDPI, Basel, Switzerland. This article is an open access article distributed under the terms and conditions of the Creative Commons Attribution (CC-BY) license (http://creativecommons.org/licenses/by/4.0/). 